\title{
Myriad Aspects in Ee- Ma- Yove \\ ${ }^{a}$ Arjun P. Kumar [AM.AR.I5ENG16021], bargi M.M. [AM.HS.P2ENG19002], 'Gopikrishnan S. [AM.HS.P2ENG19004].
}

\author{
a,b,c Department of English, Amrita Vishwa Vidyapeetham, Amritapuri, India, 20 November 2020
}

Article History: Received: 11 January 2021; Accepted: 27 February 2021; Published online: 5 April 2021

\begin{abstract}
The paper focuses on the core idea presented in the movie - death, human psychology, and narrative styles. It also proves that spicy elements are not always necessary while dealing with gloomy themes. The paper defines how the film depicts the common man's life adding their own stylisation to it, which interests the average malayali viewers who have been long saturated with the unrealistic story lines, melodramatic scenes and male- chauvinistic punch dialogues. It also deals with grief and asks a question- how you say goodbye to someone so close to you after his or her death.
\end{abstract}

Keywords: Critical reading - Narrative styles - Mob psychology - Theme - Theory

\begin{abstract}
Introduction
Ee-Ma-Yove is a realistic film directed by Lijo Jose Pellisery and written by P.F Mathews. The film's title is an abbreviation of "Eesho Mariyam Yauseppe", which in some Christian communities, is a prayer, especially whispered in the ears of the deceased. The film is a satire, set in the coastal village of Chellanam in Kochi and the story revolves around the death of the character Vavachan Mesthiri. Ee- Ma- Yove is all about death and dying, handled with a light touch. Without a shadow of doubt, this has to be one of the finest dark movies that is highly realistic. Death is an inevitable truth and the director has tried to explore how the world treats it- there are a few who are mourning the death, some who takes advantage of the demise and others who don't want to think even once that death will hit them sooner or later. It deals with grief and asks a question- how you say goodbye to someone so close to you after his or her death. Death is being glorified and the dead ones are portrayed as traveling to a greater space even after the film is completed. The complexity of human relationship in this film goes hand in hand with reality. We could see the sensitive attitude of a son to fulfil the desires of his father. The common practices in a house where the death has occurred is represented as it is in real life. To make it more clear, procedures like consoling dear ones, serving beverages, arrangements for the funeral, printing cards, informing relatives and making arrangements for the burial, and all such incidents are presented with that realistic touch. One could feel the emotions of the people and the ambience of that house. Ee-Ma-Yove explores human behaviour through black humor and realistic emotions. In the present world of technological innovations the film shows us how the human feelings remain intact and a care for their fellow beings even in a moment of despair. This paper focuses on the critical analysis of the film and explores the core ideas presented in the movie. The theories associated with the films are explained and the psychological techniques used in the films are also explored. It throws an insight into the feelings, emotions, and beaviours of people who belong to different social strata.
\end{abstract}

Central theme: The film underlines surreal fascination with death and its impact on human lives. There is no reality as strong as death. Everything else is below it. It tells a tale that is as strong as death. It deals with grief and asks a question- how you say goodbye to someone so close to you after his or her death. Death is an inevitable truth and it is depicted as an impending theme in Ee-Ma-Yove. The film starts with a funeral procession. This scene suddenly shifts from that funeral procession to the entry of Vavachan Mesthiri. At the onset of his arrival itself, the theme of impending death is evident from each and every aspects of the scene. Vavachan Mesthiri is introduced into the scene where death is an omniscient presence. The brooding melancholy played by the clarinettist is enhanced with the dialogue of Chauro. The flickering tube light also adds depth to this mood. Death hovers above the characters and the setting of Ee-Ma-Yove, like grey skies over rushing waters, and the men and women do not just think about death- they also chide, express their solidarity, threaten and flirt with one another in deathly terms. It is seen as if Vavachan Mesthiri foresees his death. $\mathrm{He}$ is seen talking to the saint of funeral, and at the very same evening, he talks to his son about his desire for a grand funeral. His son Eeshi promises him a flamboyant funeral. This is associated with a popular myth among Keralites that when the death is near, they can see and talk to the saint of funeral. Unfortunately, he dies at the same evening. The climate, ambience, colour, tone, background music and time of occurance sync with the central theme death.

Psychology: The mob psychology is portrayed brilliantly by including the minute details. The people's reaction to the death is portrayed realistically. Some people mourn at the death of their beloved. The director also scorns at people's tendency to exaggerate their emotions in front of others. The psychology of human 
beings to frame a normal death as a murder is depicted in the scene. Normally ego and detective instant is not associated with a priest. But here the priest is a person who thinks himself a Sherlock Holmes. Interestingly, the police officer is more compassionate than the priest. Chaura whom Vavachan Mesthiri mishandled tries to take vengeance by strengthening the rumour by adding their own points. A band is invited to play at the funeral, but when the situation become worse they are insulted as if they were doing something wrong. Typical Keralite culture is highlighted through minute actions and dialogues. When Eeshi asks his wife her gold chain to mortgage for funds, irrespective of the situation, she is worried about the shame that she has to face when her family visits for the funeral. Zabeth is more concerned about her looks irrespective of the situation. We can see her borrowing a chain from a neighbour claiming that her relatives will note her bare neck. Anyway she will be at the spot light of the funeral and not her neighbour. Nise's lover utilises her grief to satisfy his lust. Vavachan's wife Pennamma is very apt as a widow who has the ability to start and stop crying as the situation demands. And it also makes the scene funny too when Pennamma howls her heart out and cleverly slips in comments about their life together and about others indirectly. Pennamma pokes at a dowry's story in the midst of a tragedy when Zabeth's parents arrived there. We could also see her crying in a musical tone which appears to be comical. The business mentality of the coffin maker is also notable. He tries to gain profit despite the tragic situation Eeshi faces. Ironically, when the coffin collapses, people blame Eeshi for not buying a good quality coffin for his father. The tendency of common people to imitate the rich people's luxurious marriage or death using all their life's savings to show their pride before others gives a wrong message to the society. They all want to do something more than what their neighbours did. For that they are even ready to give up all their savings or to get into debts. In this film too we can see Eeshi promises his father a grand funeral despite the fact that he himself know that he is economically low. In order to accomplish his father's wish of a grand funeral, he sacrifices all that he has and also gets into debt.

\section{Theory}

Realism: It is a complete realistic film which portrays a negative theme out of the usual kind. The characters, dialogues, behaviour and all are true to the coastal background they belong. People treat a death in various phases. The reactions of people to the death is realistic to the core. The common practises in a house where the death has occurred is represented as it is in real life. To make it more clear, procedures like consoling dear ones, serving beverages, arrangements for the funeral, printing cards, informing relatives and making arrangements for the burial, and all such incidents are presented with that realistic touch. One could feel the emotions of the people and the ambience of that house.

Surrealism: Surrealism in literature can be defined as an artistic attempt to bridge together reality and the imagination. The closing portions are a sigh against futility of the things that we do while we are alive. Because at the end, everyone is equal- the person who goes into the grave, and the person who digs the grave, the skilled one who built an altar with a single price of wood and the unskilled grave digger who shovels out sand and makes a hole, the bird that meant a little more than a meal and the dog that was a faithful companion. Pellissery gets it right from the very beginning, from the dreamy title sequence that enters and exits the screen like a surreal metaphor.

Magical realism: Instances of magical realism are presented in this film through two anonymous characters. The scene is shifted to these characters at crucial junctures where they renders dialogues which are highly metaphorical. The two characters are seen from the beginning till the end as playing cards. Dialogues rendered by these characters appears to be inappropriate, but it has symbolic meaning.

These dialogues are conversed by the two anonymous characters:-

Man 1: "everything has gotten mixed up."

Man 2: "let it be."

Man 1: "yes, let it be. First it get mixed up, then it will get clean, then it will get mixed up,all over again."

Man 2: "true".

It points to the problems arising in the funeral house and its aftereffects and how it will end. Surprisingly, the two characters stop their card playing when all the four were dead. The ultimate scene in which we could see the dead ones- Vavachan Mesthiri, grave digger, duck, and the dog with the two anonymous characters, one wearing a black dress and the other, a white one. And there we could see two boats approaching them. People in white dress in one boat and black in another boat. It symbolically represents heaven and hell. White for heaven and black for hell. 
Conclusion: Ee- Ma- Yove is best noted for its stark realism. There are no extravagant settings in this film. He did it in such a way that audience will merge with the story for the whole time. Normally directors resort to spicy elements when dealing with gloomy themes. But Lijo Jose Pellissery does not go behind these artificialities. Instead, he sticks on to the central theme and pays full justice to it. One would feel that they are attending the funeral while watching the movie. The characters, dialogues and the behaviour are realistic to the core and all are true to the coastal background they belong. The director is successful in presenting the true essence of human life. He delves deeper into the consciences of people and portrays the reactions of people to the demise realistically. It can be concluded that $E e-M a$-Yove is partly a meditation on life and partly a comedy or grief, but it wholly and unambiguously is a film about death.

\section{REFERENCES}

1. David L Loudon \& Albert J. Della Bitta (2002) Consumer Behavior by (Chennai: Mc Graw Hill Education: 2002)

2. Thompson S.H, Teo, Yon Ding Yeong. (2003) "Assessing the consumer decision process in the digital marketplace" "Omega The International Journal of Management Science" October 20030mega 31(5):349-363 DOI: 10.1016/S0305-0483(03)00055-0

3. BHAGOWATI, DARSHANA, and DEV MALYA DUTTA. "A STUDY ON LITERATURE REVIEW FOR IDENTIFYING THE FACTORS IMPACTING DIGITAL MARKETING." International Journal of Sales \& Marketing Management Research and Development (IJSMMRD) 8.3, Aug 2018, 1-8

4. Dr. Katherine Taken Smith,(2011) "Digital Marketing Strategies that Millennial find Appealing, Motivating or Just Annoying," "Journal of Strategic Marketing" 19(6) DOI: 10.2139/ssrn.1692443

5. MAFAZI, MUHAMMAD ATRAS. "CAPITAL BUDGETING ANALYSIS IN DIGITAL MARKETING ACTIVITIES AT YES CAKE \& BAKERY." International Journal of Business Management \& Research (IJBMR) 8.6, Dec 2018, 1-8

6. Md Sajedul Islam. (2016) "An Empirical study on effectiveness and challenges of Digital Marketing in Bangladesh" International Journal of Engineering and Management Invention (IJEMI) Volume 01/Issue 01/August 2016.

7. SHUKLA, NEHA. "SOCIAL MEDIA \& ITS INFLUENCE ON CUSTOMER RELATIONSHIP IN INDIAN RETAIL SCENARIO." International Journal of Sales \& Marketing Management Research and Development (IJSMMRD) 7.4 (2017): 27-34.

8. Puneet Singh Bhatia (2017) Fundamentals of Digital Marketing (Chennai: Pearson 2017)

9. Dr. S. YUVARAJ, R. INDUMATHI(2018)" INFLUENCE OF DIGITAL MARKETING ON BRAND BUILDING" International Journal of Mechanical Engineering and Technology (IJMET) Volume 9, Issue 7, July 2018, pp. 235-243,

10. Sankaran, V. Siva, and N. Kannan. "Increasing Brand Reputation through Viral Marketing." International Journal of Sales \& Marketing Management Research and Development (IJSMMRD) 6.1 (2016): 1-8.

11. Nazimsha, S., and M. Rajeswari. "COMPARING DIGITAL MARKETING WITH TRADITIONAL MARKETING AND CONSUMER PREFERENCE, OVER WHICH MEDIUM BY TAKING CONCEPT OF ADS." International Journal of Sales \& Marketing Management (IJSMM) 7.1, Dec-Jan $2017 ; 1-12$

12. Websites: Regarding health issues in rural India www.wikipedia. 